\title{
An eco-hermeneutical perspective on inter-cultural counselling
}

J C Müller

\section{ABSTRACT}

An cco-hermeneutical perspective on inter-cultural counselling

This article draws on the valuable insights which Van Hoven's study of the kudu antelope species has brought to light. He indicates that a proper perception of any system's functioning - man and nature alike - should be based on an understanding of how the various elements of a particular system interrelate - hence the term 'ecohermeneutical'. This eco-hermeneutical approach can also be a particularly useful catalyst to stimulate inter-cultural conversation and growth. An eco-hermeneutical model for inter-cultural counselling is therefore presented with the aim of opening up the potentialities of cultures and groups within the context of pastoral care and counselling.

A recent zoological research report by a South African scientist ${ }^{1}$ will be summarised in order to clarify and introduce the systems view of reality. This will then serve as a point of departure for discussing the theme of inter-cultural counselling.

The research program was carried out during a period of drought in the northern regions of South Africa. The team investigated the occurrence of increasing deaths amongst the so-called "kudu" antelope species. Postmortems showed that the kudu starved as a result of a food shortage. There were no signs of disease or infection. While it was also conspicuous that the grazing conditions were not nearly poor enough to have caused starvation.

An analysis of the leaves of trees, normally eaten by kudu, indicated that the nutritional value was generally high (protein content of between 8 and 18 percent). Digestibility tests were also undertaken and no connection could be found between the protein content of the leaves and their digestibility. Subsequent nitrogen tests on the food and dung suggested that large quantities of protein had moved through the intestinal tract undigested.

It was decided to analyze the leaves eaten by the kudu for the presence of 
tannin (a complex series of plant chemicals). Tannin, which is usually found in the leaves and bark of trees and shrubs, serves the function of protecting the plant against infection and injury or against anything that feeds on it. In the case of the kudu, tannin-C was found. When leaves with high quantities of tannin-C are eaten, the tannin-C combines with the protein molecules, rendering the protein indigestible. The microbial enzymes responsible for the digestion of leaves in the stomach of animals are such a type of protein which combines with the tannin-C. When this happens, the enzymes cease to function - the more tannin- $\mathrm{C}$, the less enzyme action, and the digestive process is therefore retarded.

The question then remained: Why were there such high quantities of tannin-C in the leaves? Van Hoven followes the notion that when living structures are injured, they form defence mechanisms. Plants might quickly produce chemical reactions in order to counteract injuries. Therefore, a series of plants were examined to determine the levels of tannin-C present, as well as what would happen to the tannin-C production if these plants were injured. Through treating the trees harshly (i e by hitting the trees with whips and canes in order to imitate what happens when kudu browse) they discovered that the tannin-C content in the remaining leaves showed a marked increase. The increase varied from one species to another, but all of them took an average of $50-100$ hours to recover to a 'normal' state.

The circular process between animal and tree, is of such a nature that the apparently tasty leaves lose their taste after a while (due to tannin secretion), which signals to the animal the necessity of moving on. This would explain why kudu constantly move from one tree to another while browsing. However, if the animal persists in eating (for example in times of drought when there's a shortage of leaves), the leaves will become less digestible. This reduction in nutritional value may result in starvation. The process which co-evolves in a situation like that, not only decreases the kudu population, and therefore increases the probability of survival for the plants, but also increases the likelihood of the survival of the remaining animals.

Another most interesting discovery was made. The research team found that apart from the ability plants have to defend themselves, they are also capable of communicating with each other. It was found that when a certain hook thorn tree was thrashed, another hook thorn tree of the same size standing two meters away, showed a $42 \%$ increase in tannin-C after three hours. Another hook thorn tree three meters away, had $87 \%$ more tannin-C after nine hours. Research done under laboratory conditions may explain this ability of trees to communicate. When a plant's leaves are injured, aromatic compounds are released to which other plants of the same species are sensitive. 
What does this study reveal? It is clear that there is much more going on in nature than we thought and Van Hoven's study is an example of the complex circular processes that continue to exist within the ecosystem. The same circularity characterise all systems, including human systems.

A new knowledge of knowing, thinking, and deciding (epistemology) ${ }^{2}$ has developed during the last four decades. This new epistemology can (with the danger of oversimplification in mind) be explained by using three concepts: holistic, ecosystemic, and hermeneutic.

\section{$2.1 \quad$ Holistic}

The awareness is still growing that humans and the world can only be explained through a holistic perspective. All phenomena are essentially related to, and dependent on each other ${ }^{3}$. This vision developed as a reaction against the former Newtonian and Cartesian world view. According to Newton the world can only be understood by dividing it into small fragments. The whole is constructed by all the parts as essential building blocks. Furthermore, the law by which all the fragments are kept together, is that of deterministic causality. Complementary to this, the world view of Descartes divided the world in two independent parts: the spiritual world (res cogitans), and the material world (res extensa). According to this view, an absolute division was made between the natural and human sciences ${ }^{4}$.

This world view of linear causality and division, so typical of western thought, ruled academic and scientific work, and is still very much alive. Even the human sciences were built on this model and research was accordingly conducted. In the medical world this view still prevails and a human being is handled as a biochemical machine which is explainable in terms of the linear model of deterministic causality.

The psychodynamic model is founded on the same world view. Like the medical model, it tries to find the causes of emotional and mental distress in either biological malfunctioning, or trauma and conflict in the past which is now stored in the unconscious 5 . The systems view of life, on the other hand, looks at the world in terms of relationships and integration 6 . It consists of a holistic world view. A view which is not exclusive, but rather inclusive - a characteristic which could also be described with the term ecosystemic: "...different but mutually consistent concepts may be used to describe aspects and levels of reality, without the need to reduce the 
phenomena of any level to those of another"7.

2.2 Ecosystemic

The term ecology was at first only used in botany and zoology. Ecology was only used as a metaphor in the study of human communities after $1920^{8}$. In 1937 the biologist Ludwig von Bertalanfly formulated the systems theory for the first time. According to him a system is the whole of complicated units which exist in an interaction with each other. After World War Two, Von Bertalanfly and his followers described the open system with the following characteristics:

* the relationship with the surroundings

* the organised character

* the ability to stabilize itself

* the ability to develop itself

* there is always a form of organizational hierarchy, within the system and in relationship to other systems?.

It became clear that this perspective on reality gives a valuable key to the understanding of familylife. At first the General Systems Theory was a new and exciting way of explaining family dynamics; later a whole new epistemology, the ecosystemic paradigm, developed. This new epistemology is also referred to as second order cybernetics, described by Keeney ${ }^{10}$ as follows: "...cybernetics provides an aesthetic understanding of change, a type of respect, wonder, and appreciation of natural systems often overlooked by the various fields of psychotherapy..."

This ecosystemic way of knowing, thinking, and deciding also found its way into theology and specifically into pastoral theology. Traces of this view of reality are to be found in the hermeneutical and narrative approach in pastoral care and counselling11.

\section{$23 \quad$ Hermeneutic}

In its broadest meaning, hermeneutics is the art and science of interpretation. The word originated from the wing-footed messenger god, Hermes, in Greek mythology ${ }^{12}$. He had the task of transmitting divine messages into a form which could be grasped by human beings.

Hermeneutics, although a concept originally used to describe the action (science) of understanding and interpreting classical texts, is now widely used in philosophy, linguistics, all the human sciences, and in theology. The hermeneutical approach in practical theology deals with the understanding of stories - written or spoken ${ }^{13}$. When interpreting a spoken story, the speaker and the interpreter become participants in the story and thus become part of the story. Therefore, the 
interpretation of a spoken story has a unique dynamic and complexity to it - this falls within the field of pastoral theology.

Browning14 introduced the term "hermeneutical conversation" and described it as a moral conversation with any kind of human action - a classical text, work of art, letter, sermon, or political art ("political" in the sense of all social activities).

In hermeneutical conversation the emphasis is on understanding instead of explaining. Gerkin, quoting Wilhelm Dilthey ${ }^{15}$, describes the difference between the natural and human sciences with the following words: "We explain nature; man we must understand".

Understanding and interpreting is the main task of the pastoral counsellor. Involvement means interpretation. Tracy ${ }^{16}$ explains it as follows: "To experience in other than a purely passive sense (a sense less than human) is to interpret; and to be 'experienced' is to have become a good interpreter. Whether we know it or not, to be human is to be a skilled interpreter".

This is counselling: to fulfill a basic human skill. To interpret. The way in which you interpret, the attitude with which you do it, and the love, faith, and hope with which you interpret, puts this human encounter on the level of pastoral care and counselling.

There is a risk attached to this hermeneutical encounter. The risk of change and growth for both carer and client. "Care and empathy are therefore shown to be reciprocal human activities in which the subjective limits of carer and one cared for are made vulnerable. Care involves the opening of the horizon of our understanding to admit the intrusion of the world of the other in the hope and expectation that something truly new may be shared in the encounter..."17.

It may be obvious from what is said thus far, that the two terms hermeneutics and ecosystemic are closely related. However, it is important to note that each separate term has its own emphasis. In hermeutics the emphasis is on understanding and interpretation of the system; and in ecosystemic the emphasis falls on the broader system and all-inclusive ecosystem - a holistic approach. Therefore I found it useful to create a combined term: eco-hermeneutical pastoral care ${ }^{18}$. With this description of pastoral care, it is my intention to place emphasis on wholeness and on understanding, and more specifically on an understanding of wholeness.

With this term "understanding of wholeness", I definitely do not have a kind of cognitive and distant understanding of systems in mind. I am rather thinking 
of an empathetic involvement, even an appreciation of systems (also cultural systems). Not an appreciation of the system as a static phenomenon, but of the beauty (quality) of change that makes a system what it is.

Eco-hermeneutical pastoral care is pastoral care which is willing to take the risk of involvement with a system, not to explain it from the outside and even give empathetic advice from the outside, but to become part of the system and experience (and facilitate) the beauty of change. In doing so, it works towards wholeness as a ecosystemic reality and as a biblical goal.

In the light of the valuable and dynamic change-potential found in systems, pastoral care can no longer be restricted to the important, but in a sense marginal, task of caring for the individual in his or her emotional state. Emphasis must be put on the understanding of the ecosystem. Only when we understand people, and cultures within the context of the broader ecosystem, can we understand them within the framework of God's Story. God's creation and recreation involves ecosystems; involves a people, a church, which is also described in the Bible as a body (system), which we believe crosses all borders. Pastoral care, therefore, implies the involvement of all relationships. The total environment must be considered as part and parcel of pastoral care. Only when there is a growing comprehension of these patterns of interdependence and coherence, can one talk of true pastoral involvement. Hence the term: eco-hermeneutical pastoral care.

\section{4}

\section{CULTURES AND SUB-CULTURAL GROUPS}

In the light of the hermeneutical approach which we follow, inter-cultural encounters should not be seen as a problem, but as an adventure with many possibilities of growth. I have therefore decided to use the term "inter-cultural" instead of "cross-cultural". The latter conveys too much of the idea of isolated worlds. Cultures are becoming less and less isolated in our world of mobility and media coverage.

Culture is the art of actions, thoughts, reactions. Culture can't be seen. What we see are manifestations of culture in things and actions (as defined by Nida $\left.{ }^{19}\right)$. Technically speaking, culture has to do with two groups of phenomena: (1) the social actions - thoughts, actions, feelings - of a certain group; (2) the material products used by that group 20 . Culture therefore does not equal race, ethnicity, language, territory, but it is influenced by all of these. For the sake of this article, I want to use an even broader definition and include not only cultures, but subcultural groups.

When we consider the following proposals on the nature of groups by Balswick \& Morland ${ }^{21}$, it may become clear why it is important to work with the 
broader definition of culture:

1 Human groups are capable of creating symbolic meaning and thus their own view of reality.

2 Human groups are not the sole producer of reality and of human nature. Individuals and human groups maintain a dialectical relationship: human groups are a human product, but nevertheless an independent reality; and human beings are social products, but not exclusively so.

3 Human groups are free to distort reality. Christians understand that human groups do so because they exist in a state of separation or alienation from the God who created reality.

$4 \quad$ Human groups are partially motivated by selfish interests.

5 They justify their selfish behaviour on the basis of their definitions of reality. Humans are not only capable of selfish activities, but they are also capable of defining reality in such a distorted way that they do not interpret their selfish behaviour as selfish.

Human groups are a source of nurturance, identity, and support, as well as of hostility, tension, and conflict.

Each and every human being is a member of a cultural and sub-cultural group (most probably more than one sub-cultural group). We enter the counselling session both as carers and those who seek help, with all our cultural baggage (potential and filters). This only emphasizes the truth of the African view of personality as formulated in the famous words of Mbiti22: "I am because we are, and since we are, therefore I am".

We have to look for a paradigm for counselling which would be practicaltheological wisdom ${ }^{23}$. Patton 24 in his latest book, Pastoral Care in Context, argued that we have entered the communal contextual paradigm four decades ago. That may be the case in terms of theorising in the field of pastoral care and counselling. The question is, what happens in practice? Are we successful in modelling these concepts into pastoral care and counselling practice? The following proposed model is an effort to move into that direction. 

COUNSELLING

I use the term "model" only in the sense of a key that may open up far better possibilities. I am also not proposing it as the only key. It is only a key, but still the only one of which I know that might be able to open the potentialities of cultures and groups within the context of pastoral care and counselling. I do not pretend to be the designer of this key. References to other sources prove the opposite. All I did was to try to refine and polish the key in the hope that it may lead to a smoother functioning.

\subsection{Telling the story and developing a new story.}

In a previous article (see footnote 2) I used the model of Gadamer, as was modified by Tracy, which starts off by urging participants in the counselling situation to become aware of their presuppositions (Vorverständnis). Since then I have come to the conclusion that hermeneutics and a narrative approach cannot be separated. In order to understand and interpret, one must listen to the story of the other, specifically as told by him/herself. The point is that you may not be able to become aware of and voice your presuppositions without first listening to the story. In that sense it can be argued that story is implied by the first step in the Gadamer-Tracy model. Nevertheless it is of such importance in an inter-cultural situation to listen carefully to the other's story, that it should be a first and separate step. The widely used counselling model by Gerard Egan ${ }^{25}$, The skilled helper, also starts off with this step. Parker ${ }^{26}$ in his article said that one of the most important problems to be experienced in an inter-cultural situation, is defending mechanisms (Abwehrmechanismus). People tend to use their own culture in order to defend themselves from the occurrence of misunderstandings and conflict. This negative tendency, says Parker, can be creatively utilized by asking the other: "Tell me more about it?" Firstly and foremost, the other should be given the opportunity to tell her/his story.

The second motion in the Gadamer-Tracy model is when the interpreter (pastor) opens him/herself to the stimuli of the text (client). The idea here is to make a positive effort to let the text speak to you as it is. In other words, to hear the true story. That may bring a negative reaction such as shock. But it is necessary to bring all prejudice to the conscious level. It is really not possible to become consciously aware of presuppositions and prejudice without being exposed to the other text (story) as it is, and as it is told by the other person. 
With honesty I mean to be honest with oneself and with the other person. Firstly it is necessary to become aware of any presuppositions relating to the other person or her/his culture or group. The easiest way is to start this part of the discussion on the level of perceptions. We all have perceptions, ideas about the other, which may not yet have developed into prejudices, but which are coloured by our own cultural background. What is needed here, is a willingness to openly discuss these perceptions on a non-offensive basis. The idea is not to shoot at each other, but to correct our perceptions.

\section{$5.3 \quad$ Agreements (contract) about expectations and roles}

This is meta-communication 27 . Communication about communication. It is actually the making of a contract on how they are going to communicate 28 . The rules must be agreed on and both must be aware of what is happening in the counselling context.

This communication about what is happening between pastor and client, and the pastoral relationship, is called "immediacy" by Egan 29 . Even when working within one cultural setting, this is an important and very useful method. When working inter-culturally it is inevitable for the establishment of a hermeneutical relationship.

Cross-cultural counselling is not a technique which can be mastered to make the going any easier. Every time the new "game" of hermeneutics has to be played. A game always starts off with the preliminary evaluation of one another. One looks his opponent in the eye, evaluates his gear, cautiously plays the first few balls, and only then the game starts in earnest. Gadamer ${ }^{30}$ puts it as follows: "In speaking with each other we constantly pass over into the thought world of the other person; we engage him, and he engages us. So we adapt ourselves to each other in a preliminary way until the game of giving and taking - the real dialogue - begins".

\section{$5.4 \quad$ Reinterpretation of the story}

Let me again emphasize that re-interpretation of the story is not possible without giving oneself to the other and his/her story. Not only in inter-cultural counselling, but in all forms of counselling, it is of vital importance to avoid stereotypes and the tendency to take things for granted without good listening.

With listening I mean more than cognitive, intellectual listening. Good 
listening is in the first instance empathetic listening. That is to listen, and while listening, let yourself be drawn into the other's story and in that sense become part of the story, without ever trying to be culturally neutral. It is only from a position of strong identity with one's own culture, that it becomes possible to identify empathetically with the other's ${ }^{31}$. Augsburger ${ }^{32}$ dealt extensively with the issue of empathy and even introduced the term interpathy, which he defined as: "...an intentional cognitive and affective envisioning of another's thoughts and feelings from another culture, worldview, epistemology"33.

A reinterpretation should take place in the light of a new remembering 34 of the true story, a better view on the future story, and a better integration with the Story (gospel). Reinterpretion has nothing to do with diagnostic and prescriptive intervention, or with an analysis of the other culture ${ }^{35}$. It is elicitory rather than prescriptive or a structured methodological approach (as Boszormenyi-Nagy 36 describes contextual therapy). The emphasis of this model is therefore on the telling and retelling of the story, under the skilled guidance of a pastor who is also trying to understand the story of life in the light of the gospel.

\section{$5.5 \quad$ Challenge}

The process of understanding and interpretation can never be completed without this part, which we can call the hermeneutics of suspicion. A reinterpretation of the story implies the willingness to change and the willingness to challenge the other to change. Therefore the pastor must not only be open to the other "text" as it is, but also be suspicious of psychological and ideological distortions. This is of course the most difficult part of the counselling practice and usually it is only possible after several sessions and after a relationship of trust has been established. Egan ${ }^{37}$ gives helpful suggestions on how a person's strengths may be challenged rather than areas where there is a sense of vulnerability.

A person should be challenged to take responsibility for his/her own story. Responsibility for the story of the past and for the story of the future. It is often necessary to help a person to the point where it becomes possible to make decisions of real change. And then to help to the point where these decisions can be translated into strategies that fit the context ${ }^{38}$.

Part of the strategy for the future story should always be the way in which a person is going to be integrated into the broader community or ecosystem. Patton ${ }^{39}$ designed the term re-membering to stress this aspect of pastoral care. This is normally one of the advantages which the pastor has in relation to the other helping professionals who are not working within the context of a congregation or church providing communal aid. It is particularly in inter-cultural counselling that 
the need of the person would often lie on the level of belonging to a caring community. The person should be challenged to integrate his/her story into that of the community in order to experience the healing an fulfilling work of the Spirit.

I want to conclude with the Arabian folktale with which Augsburger 40 starts his second chapter: "Once there was a man who discovered how to make fire. This man, named Nour, travelled from one community to another teaching his discovery. Some received the knowledge gladly; others drove him away thinking he must be dangerous before they could learn how valuable fire could be; finally a tribe became so panic-stricken by fire that they killed him, fearing that he was a demon.

Centuries passed, and a wise man and his disciples passing through the lands discovered that one tribe reserved the secret of fire for their priests, who were warm and wealthy while the people froze; another tribe had forgotten the art but worshipped the instruments and the ashes; a third worshipped the image of Nour, who once made fire, but had forgotten the secret; a fourth retained the story and the method in their legends but no one believed or tried it; a fifth used the fire to cook, to give warmth, and to manufacture all kinds of useful goods, even bronze and iron.

The disciples were amazed at the variety of rituals and said, 'But all these procedures are in fact related to the making of fire, nothing else. We should reform these people.' The teacher said, 'very well, then. We shall retrace our journey. By the end of it, those who survive will know the real problem in teaching people and how to suggest change.'

So the teacher and disciples attempted to teach as Nour had taught. They too were scorned, abused, driven away. At the end of their journey, the master said, 'One must learn how to teach, for no one wants to be taught. First you must teach people that there is still something to be learned. Then you must learn them how to learn. Then you must wait until they are ready to learn. Then you will find that they learn what they imagine is to be learned, not what they really must learn. When you have learned all this, then you can devise a way to teach". (Adapted from Shah 1967).

Those who want to bring change through pastoral care and counselling, should take note.

\section{NOTES:}

1 Van Hoven, 1984.

2 E H Auerswald, "Thinking about thinking in family therapy", Family Process 24/1 (March 1994), 1-12. 
3 F Capra, The turning point, London 1983, 285.

4 Capra, op cit, 45.

5 L Hoffman, Foundations of family therapy. A conceptual framework for systems change, New York 1981, 6.

6 Capra, op cit, 286.

$7 \quad$ Capra, op cit, 89.

8 S W P Grobbelaar \& S Louw, "Ekologie as metafoor vir gemeenskapsontwikkeling", Die Maatskaplikewerk-Navorser Praktisyn 3/2 (Junie 1990), 15-22.

9 W van Tilburg, "Gezondheid als mensbeschouwing", in: Heil, heling, gezondheid, edited by G Heitink \& J Veenhof, s'-Gravenhage 1990, 33.

10 B P Keeney, Aesthetics of change, New York 1983, 8.

11 R Bons-Storm, Hoe gaat het met jou?, Kampen 1989. C V Gerkin, The living human document. Revisioning pastoral counseling in a hermeneutical mode, Nashville 1984. H J Veltkamp, Pastoraat als gelijkenis, Kampen 1988.

12 Gerkin, op cit, 19.

13 Bons-Storm, op cit, 85.

14 D S Browning, A fundamental practical theology, Minneapolis 1991, 39.

15 Gerkin, op cit, 41.

16 D Tracy, Plurailty and ambiquity. Hermeneutics, religion, hope. San Francisco 1987, 9.

17 Gerkin, op cit, 45.

18 Compare my previous articles on this theme, for instance: Pastoral care in Post-Apartheid South Africa, Praktiese Teologie in Suid-Afrika, 6/2 (1991), 184-192.

19 E A Nida, Customs and cultures, New York 1954, 28.

20 G K Parker, "Seelsorge als kulturelles Problem", Wege zum Menschen 44/6 (Aug/Sept 1992), 307-320.

21 J O Balswick \& J O Morland, Social problems. A Christian understanding and response, Grand Rapids 1990,26.

22 J S Mbiti, African religions and philosophy, London 1971, 
23 In another article, Practical-theological wisdom in the context of pastoral marriage and family therapy [Praktiese Teologie in Suid-Afrika 9/1 (1994)], 20-28. I explained my view on practical-theological wisdom.

$24 \mathrm{~J}$ Patton, Pastoral care in context. An introduction to pastoral care, Louisville, Kentucky 1993, 4.

25 G Egan, The skilled helper, Pacif Grove, California 1989.

26 Parker, op cit, 312-3.

27 G Bateson, Mind and nature, New York 1979, 116.

28 Parker, op cit, 314.

29 Egan, op cit, 224-9.

30 H Gadamer, Philosophical hemeneutics, Berkeley 1976, 56-57.

$31 \quad$ Parker, op cit, 314.

32 D W Augsburger, Pastoral counseling across cultures, Philadelphia 1986, $27-$ 32.

33 Augsburger, op cit, 31.

34 Patton referred to Freud who said that the weakest point of our mental health is often the weakness of our memory. Patton quoted the words of Milan Kundere (1993:31): The heavier the burden, the closer our lives come to the earth, the more real and truthful they become, op cit, 31 .

35 That is why I am not in favour of Patton's use of the phrase "cultural ethnographer", op cit.

36 I Boszormenyi-Nagy \& B R Kramer, Between give and take. A clinical guide to contextual therapy, New York 1986.

37 Egan, op cit, 238-9.

38 Egan, op cit, 325-341.

$39 \quad$ Patton, op cit, 39.

40 Augsburger, op cit, 48. 